\title{
Factors Affecting Adherence to Antiretroviral Treatment among HIV/AIDS Patients in Turkey
}

\section{Türkiye'de HIV/AIDS Hastalarında Antiretroviral Tedavi Uyumunu Etkileyen Faktörler}

\author{
Hanife Nur KARAKOÇ (ID), Selçuk KAYA ${ }^{2}$ (IID), Merve AYDIN³ (IDD), iftihar KÖKSAL ${ }^{4}$ (IID)
}

\footnotetext{
${ }^{1}$ Clinic of Infectious Diseases and Clinical Microbiology, Bitlis Tatvan State Hospital, Bitlis, Turkey

${ }^{2}$ Department of Infectious Diseases and Clinical Microbiology, Karadeniz Technical University Faculty of Medicine, Trabzon, Turkey

${ }^{3}$ Department of Medical Microbiology, KTO Karatay University Faculty of Medicine, Konya, Turkey

${ }^{4}$ Department of Infectious Diseases and Clinical Microbiology, Acıbadem Mehmet Ali Aydınlar University Faculty of Medicine, istanbul, Turkey
}

Cite this article as: Karakoç HN, Kaya S, Aydın M, Köksal i. Factors affecting adherence to antiretroviral treatment among HIV/AIDS patients in Turkey. FLORA 2021;26(4):679-89.

\begin{abstract}
Introduction: Adherence to antiretroviral treatment (ART) is critical for the success of Human Immunodeficiency Virus (HIV) infection treatment. There is no approved consensus that defines adherence. In this study, it was aimed to examine the adherence rate of our patients with high-efficacy ART and to determine the factors affecting treatment adherence.

Materials and Methods: Seventy-two patients admitted to the study between January 1, 2018 and July 31, 2018 with the diagnosis of HIV/AIDS who received ART for at least three months and agreed to participate in the study were included in the study. The effect of treatment adherence was investigated by examining the sociodemographic and clinic characteristics and laboratory findings, and moods of the patients. Treatment adherence of the patients was evaluated with the Center for Adherence Support Evaluation (CASE) adherence questionnaire and pill counting method. The Hamilton Depression Rating Scale questionnaire was used to investigate the effect of depression severity on treatment adherence in patients.

Results: Of the patients, $72.2 \%$ were males and $27.8 \%$ were females. Mean age of the patients was $44.9 \pm 14.8$ years. Of the patients, $59.7 \%$ were defined as treatment compatible. Sixty (83.3\%) patients used a single tablet regimen. The most commonly used combination was tenofovir alafenamide-emtricitabine-elvitegravir-cobicistate. Patients' age, disease duration, frequency of follow-up clinic, depressive mood, substance use, and HIV positivity in their partners were found effective on treatment adherence. However, sex, marital and educational status, occupation, residential area, transmission route, duration on ART, ART regimen, ART treatment revision, recent CD4+ T lymphocyte count, recent viral load, side effect, additional treatments, antibiotic prophylaxis, smoking habit, alcohol use, comorbidity, co-infection were not statistically associated with treatment adherence.

Conclusion: Sufficient awareness should be created by allocating enough time to patients, and patients should be followed up more frequently. Since alcohol and substance use affects treatment adherence, support should be sought from relevant institutions to limit alcohol and substance use in patients. Depressive mood is more common in HIV/AIDS patients compared to the normal population and negatively affects treatment adherence.
\end{abstract}

Key Words: ART; Depression; HIV/AIDS; Treatment adherence

Received/Geliș Tarihi: 28/07/2021 - Accepted/Kabul Ediliș Tarihi: 12/10/2021

${ }^{\circ}$ Copyright 2021 by Flora. Available on-line at www.floradergisi.org. 
ÖZ

\title{
Türkiye'de HIV/AIDS Hastalarında Antiretroviral Tedavi Uyumunu Etkileyen Faktörler
}

\author{
Hanife Nur KARAKOÇ ${ }^{1}$, Selçuk KAYA², Merve AYDIN³ , iftihar KÖKSAL ${ }^{4}$
}

\footnotetext{
${ }^{1}$ Bitlis Tatvan Devlet Hastanesi, İnfeksiyon Hastalıkları ve Klinik Mikrobiyoloji Klinig̃i, Bitlis, Türkiye

${ }^{2}$ Karadeniz Teknik Üniversitesi Tıp Fakültesi, İnfeksiyon Hastalıkları ve Klinik Mikrobiyoloji Anabilim Dalı, Trabzon, Türkiye

3 KTO Karatay Üniversitesi Tıp Fakültesi, Tıbbi Mikrobiyoloji Anabilim Dalı, Konya, Türkiye

${ }^{4}$ Acıbadem Mehmet Ali Aydınlar Üniversitesi Tıp Fakültesi, İnfeksiyon Hastalıkları ve Klinik Mikrobiyoloji Anabilim Dalı, İstanbul, Türkiye
}

\begin{abstract}
Giriş: Antiretroviral tedaviye (ART) uyum insan Bağışılık Yetmezliği Virüsü (HIV) infeksiyonu tedavisinde başarılı olmak için kritik noktadır. Uyumu tanımlayan kabul görmüş ortak bir görüş mevcut değildir. Bu çalışmada, hastalarımızın yüksek etkinlikli ART'ye uyum oranını incelemek ve tedavi uyumunu etkileyen faktörlerin belirlenmesi amaçlanmıştır.
\end{abstract}

Materyal ve Metod: 1 Ocak 2018-31 Temmuz 2018 tarihleri arasında polikliniğe başvuran HIV/AIDS tanısıly takipli, en az üç ay ART kullanım öyküsü olan ve çalısmaya katılmayı kabul eden 72 hasta çalışmaya dahil edildi. Hastaların sosyodemografik ve klinik özellikleri, laboratuvar bulguları ve duygu durumları incelenerek uyuma etkisi araştırıldı. Hastaların tedavi uyumu CASE uyum anketi ve hap sayım metodu ile değerlendirildi. Hastalarda tedavi uyumuna depresyon şiddetinin etkisini araştırmak için Hamilton Depresyon Değerlendirme ölçeği anketi kullanıldı.

Bulgular: Hastaların \%72.2'si erkek, \%27.8'i kadındı. Hastaların ortalama yaşı $44.9 \pm 14.8$ yıldı. Hastalarımızın \%59.7'si tedaviye uyumlu olarak tanımlandı. 60 (\%83.3) hasta tek tablet rejimi kullandı. En sık kullanılan kombinasyon tenofovir alafenamid-emtrisitabin-elvitegravir-kobisistat idi. Hastaların yaşı, hastalık süresi, klinik takip sıkığı, depresif duygu durum, madde kullanımı ve partnerlerinde HIV pozitifliğinin tedaviye uyum üzerinde etkili olduğu bulundu. Ancak cinsiyet, medeni ve eğitim durumu, meslek, yerleşim yeri, bulaşma yolu, ART kullanma süresi, ART rejimi, ART tedavi revizyonu, son CD4+ T lenfosit sayısı, son viral yük, yan etki, ek tedaviler, antibiyotik profilaksisi, sigara alışkanlığı, alkol kullanımı, komorbidite, koinfeksiyon istatistiksel olarak tedaviye uyumuyla ilişkili değildi.

Sonuç: Hastalara yeterli zaman ayırılarak gerekli farkındalık oluşturulmalı ve hastalar daha sık aralıklarla izlenmelidir. Alkol ve madde kullanımı tedavi uyumunu etkilediğinden, hastalarda alkol ve madde kullanımını sınırlandırmaya yönelik olarak ilgili kurumlardan destek alınmalıdır. HIV/AIDS hastalarında depresif duygu durumu normal popülasyona göre daha yaygın olup tedavi uyumunu olumsuz etkilemektedir.

Anahtar Kelimeler: ART; Depresyon; HIV/AIDS; Tedavi uyumu

\section{INTRODUCTION}

According to the data of Joint United Nations Programme on Human Immunodeficiency Virus/ Acquired Immunodeficiency Syndrome (HIV/AIDS) [UNAIDS], approximately 37.6 million people worldwide live with HIV. In 2020, 1.5 million people were infected with HIV and 690.000 people died from HIV-related diseases ${ }^{[1]}$. According to the data of the General Directorate of Public Health of Turkey, Department of Infectious Diseases, there were 26.447 persons living with HIV and 1974 AIDS cases reported from 1985 to 31 January $2021^{[2]}$.

UNAIDS plans to end the AIDS epidemic at the years 2030. For this reason, the 90-90-90 target has been set, which aims to diagnose 90\% of people living with HIV, initiate antiretroviral treatment (ART) in 90\% of those diagnosed, and suppress the virus in $90 \%$ of those whose treatment is initiated. It is reported that by 2030, with the increase in accessibility to ART, AIDS-related deaths will decrease by $80 \%$ and the number of new HIV infections will decrease by $90 \%[3,4]$.

HIV can be treated with lifelong ART. ART is the cornerstone of HIV treatment as it prevents disease progression, improves quality of life, reduces the risk of morbidity-mortality, and the risk of transmission by decreasing the viral load level to undetectable levels in patients ${ }^{[5,6]}$. However, compliance to ART is very important. High ART 
compliance rates are critical to suppress HIV viral load, delay progression to AIDS, and reduce the risk of HIV transmission ${ }^{[6,7]}$. Although it also depends on the treatment regimen, $80 \%$ to $95 \%$ compliance is required to achieve success ${ }^{[5]}$. Poor adherence to ART leads to insufficient suppression of the virus, the emergence of drug-resistant strains, and an increased risk of HIV transmission. It also results in a reduction in CD4 count and higher death rates ${ }^{[8,9]}$.

While an average drug non-adherence rate of $24.8 \%$ is reported in most patients with chronic diseases, the level of adherence to ART in HIV is higher compared to other chronic diseases ${ }^{[9]}$. The level of compliance with ART and the factors affecting it vary from country to country and from region to region, depending on culture, religion, educational status, economic situation and health system ${ }^{[10]}$. Determining the level of adherence to ART and the factors affecting compliance will assist in the development of intervention strategies to improve adherence to $\mathrm{ART}^{[9,11]}$.

The level of adherence to ART has been reported as $63.9 \%$ in $\operatorname{Iran}^{[12]}, 70.4 \%$ in India ${ }^{[9]}$, $73.1 \%$ in Ethiopia ${ }^{[10]}, 82 \%$ in Russia ${ }^{[13]}, 84 \%$ in Myanmar ${ }^{[11]}, 85.5 \%$ in China ${ }^{[14]}, 87.4 \%$ in Nepal ${ }^{[8]}$.

To date, there has been a limited number of studies on ART compliance and factors affecting compliance in Turkey ${ }^{[15]}$. In this study, it was aimed to determine the level of ART compliance and the factors affecting compliance in people living with HIV in Trabzon province and its surroundings, located in the North of Turkey.

\section{MATERIALS and METHODS}

Our study was performed as a cross-sectional prospective observational study at Karadeniz Technical University Faculty of Medicine, Clinic of Infectious Diseases and Clinical Microbiology between 1 January 2018 and 31 July 2018. Ethics committee approval was obtained with the decision of Karadeniz Technical University Faculty of Medicine Clinical Research Ethics Committee dated 15.01.2018 and numbered 2017/216.

During the study, 251 patients diagnosed with HIV/AIDS and receiving ART applied to the Infectious Diseases Clinic for treatment follow-up. In the HIV/AIDS diagnostic algorithm, the test was repeated in patients whose serum was found to be anti-HIV positive by ELISA method. Positive samples were confirmed with the Western-Blot test performed in the National AIDS Verification and Reference Laboratory affiliated to the Department of Microbiology Reference Laboratories of the Turkish Public Health Institution, and the diagnosis of HIV/AIDS was made. Among 251 patients, 72 patients who met the inclusion criteria and agreed to voluntarily participate in the study were included in the study. Inclusion criteria were being older than 18 years of age, taking ART for at least three months, not interrupting follow-up for more than two months and volunteering. Exclusion criteria were being younger than 18 years of age, duration of ART use less than three months, interrupting follow-up for more than two months, being pregnant, and a desire to withdraw from the study.

All participants were informed with the Informed Consent Form and their consent was obtained using the Consent Patient Information Form. Data of the participants were obtained from the HIV/AIDS follow-up forms and the hospital database. After the informed consent form was obtained, the patients' sociodemographic characteristics, route of transmission, disease duration, ART duration, ART regimen, ART change, side effects, drug resistance, current CD4+ $\mathrm{T}$ lymphocyte count and HIV RNA level, clinical characteristics such as follow-up frequency, physical examination and laboratory findings, comorbid diseases, additional treatments used, additional viral disease and HIV positivity in the partner, smoking, alcohol and substance use were recorded in specially prepared HIV/AIDS follow-up forms filled out for each patient. The recorded data was evaluated prospectively.

In our study, treatment compliance and severity of depression were determined by indirect methods in these patients who were followed up with the diagnosis of HIV/AIDS. In order to measure treatment compliance and level of depression, all participants were asked to fill out a questionnaire using face-to-face interview method. Data collection was done in a private room of the clinic with the confidentiality of the 
participant.

A compliance questionnaire was prepared using the Center for Adherence Support Evaluation (CASE) criteria and pill counting method based on the ratio of the number of drugs prescribed and the number of drugs used were used to evaluate treatment adherence. This test is a test based on patient statements, consisting of questions to determine treatment compliance. According to the compliance survey, patients with a score of 10 or more were considered compliant, and patients with a score of 10 or less were considered non-compliant. In the pill counting method, the score $(\%)=$ number of pills actually taken/number of pills to be taken $\times 100$, according to the formula, if the score is $\geq 95 \%$, the treatment is considered compatible if it is below $95 \%$, the treatment is considered incompatible $e^{[16]}$.

A 17-item Hamilton Depression Rating Scale (HAM-D) questionnaire, which evaluates mood, was used to investigate the effect of depression level on patients' adherence to treatment. A score of 0-7 was considered as no depression, and 8 and above was considered depression ${ }^{[17]}$.

\section{Statistical Analysis}

IBM Statistical Package for the Social Sciences (SPSS) 23 (IBM Corp. Released 2010. IBM SPSS Statistics for Windows, Version 23.0 Armonk, NY: IBM Corp) was used for statistical analysis of the data. Continuous variables were expressed as mean \pm standard deviation and median (maximum-minimum), and categorical variables were expressed as $\mathrm{n}(\%)$. The conformity of the measurement data to normal distribution was examined with the One-Sample Kolmogorov Smirnov test. Since the data did not show normal distribution, Mann-Whitney $U$ test was used for comparisons of two independent groups. Chi-square test was used to compare qualitative data. Statistical significance level was accepted as $\mathrm{p}<0.05$.

\section{RESULTS}

Out of 72 patients, 43 (59.7\%) patients who scored above 10 according to the CASE compliance test were considered compliant with the treatment. Of the 72 patients we followed up with the diagnosis of HIV/AIDS, 52 (72.2\%) were males and 20 (27.8\%) were females. Of the treatment-compliant patients, 10 (23.3\%) were females and 33 (76.7\%) were males. There was no statistically significant difference between sex and treatment compliance $(p=0.438)$ (Table 1$)$.

Mean age of the patients was $44.9 \pm 14.8$ years. While the mean age of men was $43.9 \pm$ 19.0 years, the mean age of women was 47.6 \pm 18.9 years. The patients were most frequently between the ages of 31-40 and 51-60. The age range with the highest compliance was 51-60 (32.6\%), followed by 31-40 (25.5\%). Compliance with treatment was found to be statistically significantly higher in patients aged 51-60 years $(p=0.028)$ (Table 1). Of the patients, 55.6\% were married, 30.5\% were single, and 13.9\% were widowed-divorced. There was no statistically significant difference between the patients' marital status and adherence to treatment $(p=0.769)$ (Table 1).

When the educational status of the patients was examined, 40 (55\%) were illiterate-primary school graduates, 18 (25\%) were high school graduates, and 14 (19.4\%) were university graduates. There was no statistically significant difference between education status and adherence to treatment $(p=0.135)$ (Table 1$)$. When the occupational status of the patients was examined, 35 (48.7\%) were civil servants, 23 (31.9\%) were unemployed and 14 (19.4) were retired. There was no statistically significant difference between the occupational groups of the patients and their adherence to treatment $(p=0.146)$ (Table 1$)$.

While 39 (54.2\%) patients were residing in urban and its surroundings, 33 (45.8\%) were living in other regions. Patients from other regions preferred the province of Trabzon for reasons such as fear of the disease being known in the region they live in and being stigmatized. There was no statistically significant difference between the settlement and treatment compliance $(p=$ 0.703) (Table 1).

Heterosexual transmission was detected in 58 $(80.5 \%)$ patients, homosexual transmission in eight (11.1\%) patients, blood transfusion in three patients $(4.2 \%)$, surgical transmission in two (2.8\%) patients and mother-to-child transmission 


\begin{tabular}{|c|c|c|c|c|}
\hline \multirow[b]{2}{*}{ Variables } & \multicolumn{2}{|c|}{ ART Adherence } & \multirow[t]{2}{*}{ p } & \multirow[t]{2}{*}{ OR (\%95) Cl } \\
\hline & Adherent n (\%) & Not adherent n (\%) & & \\
\hline Gender & & & 0.438 & \\
\hline Male & $33(63.5 \%)$ & $19(36.5 \%)$ & & $1.737(0.612-4.926)$ \\
\hline Female & $10(50.0 \%)$ & $10(50.0 \%)$ & & 1 \\
\hline Age & & & 0.028 & \\
\hline $18-30$ & $8(57.1 \%)$ & $6(42.9 \%)$ & & $2.667(0.538-13.212)$ \\
\hline $31-40$ & $11(68.8 \%)$ & $5(31.3 \%)$ & & $4.400(0.889-21.780)$ \\
\hline $41-50$ & $6(42.9 \%)$ & $8(57.1 \%)$ & & $1.500(0.303-7.432)$ \\
\hline $51-60$ & $14(87.5 \%)$ & $2(12.5 \%)$ & & $14.000(2.080-94.236)$ \\
\hline $61<$ & $4(33.3 \%)$ & $8(66.7 \%)$ & & 1 \\
\hline Marital status & & & 0.769 & \\
\hline Single & $13(59.1 \%)$ & $9(40.9 \%)$ & & $1.444(0.321-6.493)$ \\
\hline Married & $25(62.5 \%)$ & $15(37.5 \%)$ & & $1.667(0.413-6.726)$ \\
\hline Divorced & $5(50.0 \%)$ & $5(50.0 \%)$ & & 1 \\
\hline Educational status & & & 0.135 & \\
\hline Illiterate-primary school & $20(50.0 \%)$ & $20(50.0 \%)$ & & 1 \\
\hline High school & $12(66.7 \%)$ & $6(33.3 \%)$ & & $2.000(0.627-6.377)$ \\
\hline University & $11(78.6 \%)$ & $3(21.4 \%)$ & & $3.667(0.887-15.156)$ \\
\hline Occupation & & & 0.146 & \\
\hline Civil servants & $23(65.7 \%)$ & $12(34.3 \%)$ & & $2.492(0.846-7.338)$ \\
\hline Unemployed & $10(43.5 \%)$ & $13(56.5 \%)$ & & $3.250(0.783-13.482)$ \\
\hline Retired & $10(71.4 \%)$ & $4(28.6 \%)$ & & 1 \\
\hline Residential area & & & 0.703 & \\
\hline Urban & $22(56.4 \%)$ & $17(43.6 \%)$ & & 1 \\
\hline Other regions & $21(63.6 \%)$ & $12(36.4 \%)$ & & $1.352(0.523-3.499)$ \\
\hline HIV transmission route & & & $\mathrm{N} / \mathrm{A}$ & \\
\hline Homosexual transmission & $33(56.9 \%)$ & $25(43.1 \%)$ & & 1 \\
\hline Heterosexual transmission & $4(50.0 \%)$ & $4(50.0 \%)$ & & $0.758(0.172-3.328)$ \\
\hline Blood transfusion & $3(100.0 \%)$ & 0 & & $\mathrm{~N} / \mathrm{A}$ \\
\hline Mother-to-child transmission & $1(100.0 \%)$ & 0 & & $\mathrm{~N} / \mathrm{A}$ \\
\hline Dental procedures & $2(100.0 \%)$ & 0 & & $\mathrm{~N} / \mathrm{A}$ \\
\hline Disease duration & & & 0.025 & \\
\hline$<5$ years & $15(62.5 \%)$ & $9(37.5 \%)$ & & $4.167(1.003-17.305)$ \\
\hline $6-10$ years & $24(70.6 \%)$ & $10(29.4 \%)$ & & $6.000(1.518-23.714)$ \\
\hline$>10$ years & $4(28.6 \%)$ & $10(71.4 \%)$ & & 1 \\
\hline Duration on ART & & & 0.363 & \\
\hline$<5$ years & $24(64.9 \%)$ & $13(35.1 \%)$ & & $2.769(0.660-11.617)$ \\
\hline $6-10$ years & $15(60.0 \%)$ & $10(40.0 \%)$ & & $2.250(0.504-10.053)$ \\
\hline$>10$ years & $4(40.0 \%)$ & $6(60.0 \%)$ & & 1 \\
\hline
\end{tabular}


Table 1. Distribution of socio-demographic and clinical characteristics of patients and its effect on ART adherence (continue)

\begin{tabular}{|c|c|c|c|c|}
\hline \multirow[b]{2}{*}{ Variables } & \multicolumn{2}{|c|}{ ART Adherence } & \multirow[t]{2}{*}{$\mathrm{p}$} & \multirow[t]{2}{*}{ OR $(\% 95) \mathrm{Cl}$} \\
\hline & Adherent $\mathrm{n}(\%)$ & Not adherent $\mathrm{n}(\%)$ & & \\
\hline Recent CD4 (cells/mm³) & & & 0.320 & \\
\hline$<500$ & $13(72.2 \%)$ & $5(27.8 \%)$ & & $1.300(0.267-6.327)$ \\
\hline $500-1000$ & $21(52.5 \%)$ & $19(47.5 \%)$ & & $0.553(0.143-2.134)$ \\
\hline$>1000$ & $8(66.7 \%)$ & $4(33.3 \%)$ & & 1 \\
\hline Recent Viral Load (HIV RNA) & & & 0.061 & \\
\hline$<1000$ & $43(62.3 \%)$ & $26(37.7 \%)$ & & $\mathrm{N} / \mathrm{A}$ \\
\hline$\geq 1000$ & 0 & $3(100.0 \%)$ & & N/A \\
\hline ART regimens & & & 1.000 & \\
\hline $2 \mathrm{NRTI}+\mathrm{INSTI}$ & $40(59.7 \%)$ & $27(40.3 \%)$ & & 1 \\
\hline Other (2 NRTI + NNRTI/2 NRTI + PI) & $3(60.0 \%)$ & $2(40.0 \%)$ & & $1.013(0.158-6.469)$ \\
\hline ART treatment revision & & & 1.000 & \\
\hline No & $16(59.3 \%)$ & $11(40.7 \%)$ & & 1 \\
\hline Yes & $27(60.0 \%)$ & $18(40.0 \%)$ & & $1.031(0.390-2.726)$ \\
\hline Side effect & & & 0.157 & \\
\hline No & $38(64.4 \%)$ & $21(35.6 \%)$ & & $2.895(0.840-9.984)$ \\
\hline Yes & $5(38.5 \%)$ & $8(61.5 \%)$ & & 1 \\
\hline Antibiotic prophylaxis & & & 0.679 & \\
\hline No & $40(60.6 \%)$ & $26(39.4 \%)$ & & $1.538(0.288-8.211)$ \\
\hline Yes & $3(50.0 \%)$ & $3(50.0 \%)$ & & 1 \\
\hline Additional treatment & & & 0.083 & \\
\hline No & $32(68.1 \%)$ & $15(31.9 \%)$ & & $2.715(0.999-7.380)$ \\
\hline Yes & $11(44.0 \%)$ & $14(56.0 \%)$ & & 1 \\
\hline Follow-up clinic & & & 0.008 & \\
\hline One times a year & $13(46.4 \%)$ & $15(53.6 \%)$ & & 1 \\
\hline Two times a year & $7(43.8 \%)$ & $9(56.3 \%)$ & & $0.897(0.261-3.088)$ \\
\hline Three times a year & $23(82.1 \%)$ & $5(17.9 \%)$ & & $5.308(1.568-17.967)$ \\
\hline Smoking habit & & & 0.565 & \\
\hline No & $22(64.7 \%)$ & $12(35.3 \%)$ & & $1.484(0.547-3.840)$ \\
\hline Yes & $21(55.3 \%)$ & $17(44.7 \%)$ & & 1 \\
\hline Alcohol use & & & 0.077 & \\
\hline No & $37(66.1 \%)$ & 19 (33.9\%) & & $3.246(1.024-10.285)$ \\
\hline Yes & $6(37.5 \%)$ & $10(62.5 \%)$ & & 1 \\
\hline Substance use & & & 0.023 & \\
\hline No & $43(63.2 \%)$ & $25(36.8 \%)$ & & $\mathrm{N} / \mathrm{A}$ \\
\hline Yes & 0 & $4(100.0 \%)$ & & $\mathrm{N} / \mathrm{A}$ \\
\hline
\end{tabular}




\begin{tabular}{|c|c|c|c|c|}
\hline \multirow[b]{2}{*}{ Variables } & \multicolumn{2}{|c|}{ ART Adherence } & \multirow[t]{2}{*}{$\mathbf{p}$} & \multirow[t]{2}{*}{ OR (\%95) Cl } \\
\hline & Adherent n (\%) & Not adherent n (\%) & & \\
\hline $\begin{array}{l}\text { Comorbidity of other chronic } \\
\text { illness }\end{array}$ & & & 0.560 & \\
\hline No & $25(64.1 \%)$ & $14(35.9 \%)$ & & $1.488(0.577-3.838)$ \\
\hline Yes & $18(54.5 \%)$ & $15(45.5 \%)$ & & 1 \\
\hline Additional viral disease & & & 1.000 & \\
\hline No & $39(60.0 \%)$ & $26(40.0 \%)$ & & 1 \\
\hline Yes & $4(57.1 \%)$ & $3(42.9 \%)$ & & $1.385(0.237-8.104)$ \\
\hline Presence of HIV in partners & & & 0.025 & \\
\hline No & $33(70.2 \%)$ & $14(29.8 \%)$ & & $3.536(1.281-9.760)$ \\
\hline Yes & $10(40.0 \%)$ & $15(60.0 \%)$ & & 1 \\
\hline Case Adherence Index & & & $<0.001$ & \\
\hline$\leq 10$ & 0 & $29(100.0 \%)$ & & N/A \\
\hline$>11$ & $43(100.0 \%)$ & 0 & & N/A \\
\hline Depression Score (HAM-D) & & & 0.007 & \\
\hline$\leq 7$ & $30(75.0 \%)$ & $10(25.0 \%))$ & & 4.385 (1.605-11.977) \\
\hline$\geq 8$ & $13(40.6 \%)$ & $19(59.4 \%)$ & & 1 \\
\hline
\end{tabular}

in one (1.4\%) patient. $\mathrm{p}$ value could not be given because the number was small (Table 1).

Three (4.1\%) patients had co-infection with Hepatitis B virus and four (5.5\%) patients with Hepatitis C virus. When patients with hepatitis co-infection were compared in terms of treatment compliance, no statistically significant difference was found $(p=1.000)$ (Table 1). Comorbid disease was present in 33 (46\%) of the patients. The most common comorbid diseases were hypertension (16.7\%) and diabetes (13.9\%). There was no statistically significant difference between the presence of comorbid disease and treatment compliance $(p=0.560)$ (Table 1).

Twenty-five (34.7\%) patients were using additional drugs in addition to ART. There were no patients who took five or more drugs, which is called polypharmacy. The most common was the use of drugs for hypertension. It was seen that the use of additional drugs did not affect treatment compliance $(p=0.083)$ (Table 1$)$. Six of the patients were using antibiotic prophylaxis. There was no statistically significant difference between antibiotic use and treatment compliance $(p=0.679)$ (Table 1).
Twenty-eight (38.9\%) patients came for control in three-month periods, 28 (38.9\%) in sixmonth periods, and 16 (22.2\%) patients in fourmonth periods. A statistically significant difference was found between the frequency of follow-up and adherence to treatment $(p=0.08)$ (Table 1).

When the treatment combinations of 72 patients receiving ART were examined, 67 (93\%) patients received 2 NRTI + INSTI treatment regimens, while 60 (83.3\%) patients used a single tablet regimen. The most commonly used combination was tenofovir alafenamide/emtricitabine + elvitegravir/cobicistat (TAF/FTC + EVG/c). There was no statistically significant relationship between the treatment combination and treatment compliance $(p=1.000)$ (Table 1). Initial treatment regimens were changed in 45 (62.5\%) of the patients. The patients had a mean treatment history of $49.4 \pm 38.8$ months before ART revision. When treatment compliance of the patients who underwent treatment revision and those who did not, no difference was found between treatment compliance ( $p=1.000)$ (Table 1$)$. Treatment revision was made in 25 of the patients in order to simplify the treatment, in 16 of them due 
to side effects, and in four of them because of resistance.

Thirty-seven (51.4\%) patients had been on ART for 5 years or less, 25 (34.8\%) for 6-10 years, and 10 (13.8\%) for more than 10 years. There was no statistically significant difference between the duration of ART and adherence to treatment $(p=0.363)$ (Table 1$)$. Side effects associated with ART were seen in 13 patients (18.1\%). Side effects related to the central nervous system were most common ( $\mathrm{n}=8,11.1 \%)$. Gastrointestinal side effects $(n=3,4.2 \%)$ were in the second place. When the relationship between side effects and treatment compliance was examined, no statistically significant difference was found $(p=0.157)$ (Table 1).

While 34 of the patients (47.3\%) were followed for 6-10 years, 24 (33.3\%) were followed for $<5$ years, 14 (19.4\%) were followed for more than 10 years with HIV positivity. A statistically significant difference was found between disease duration and treatment compliance $(p=0.025)$ (Table 1).

At the last visit of our patients who received treatment, HIV RNA test was negative except for 3 patients. CD4 rates were 29.2\% $\pm 10.5 \%$, and absolute CD4 values were $729 \pm 348.3$ cells/ mm3. When HIV RNA and CD4 values of the patients were compared with treatment compliance, it was found that there was no significant effect on compliance ( $p>0.05$ ). HIV RNA-positive patients were non-adherent patients. These patients were at a mean of $60 \pm 18.4$ months of treatment. Absolute CD4 values were 209.5 \pm 321.7 cells $/ \mathrm{mm}^{3}$. Two of these patients were severe according to the HAM-D depression score, and the other patient was suitable for the definition of moderate depression (Table 1).

Thirty-eight (52.8\%) patients were smokers. When smoking and treatment compliance were compared, no statistically significant difference was found $(p=0.565)$. Sixteen of the patients (22.2\%) consumed alcohol. The patients defined themselves as social drinkers and took them on special days or once a week $(p=0.077)$. Four of the patients (5.6\%) used recreational drugs (marijuana, cocaine). Compliance with treatment was found to be statistically significantly lower in those with recreational drug use $(p=0.023)$ (Table 1).

The partners of 25 (34.7\%) of the patients had HIV positivity. It was determined that the treatment compliance of the patients whose partner was not HIV positive was better than the patients whose partner was positive $(p=0.025)$ (Table 1).

Thirty-two patients (44.4\%) had depressive mood. $40.6 \%$ of patients with depressive mood were compliant with treatment. Patients with depressive mood had lower adherence to treatment. A statistically significant difference was found when depressive mood and treatment compliance were compared $(p=0.007)$ (Table 1$)$.

\section{DISCUSSION}

It is important to define factors affecting compliance with ART in order to ensure the efficacy of treatment in HIV/AIDS patients ${ }^{[18]}$. Various methods (such as pill count methods ${ }^{[18,}$ 19], CEAT-VIH questionnaire ${ }^{[20]}$, SEA-ART compliance scale ${ }^{[21]}$, and CASE criteria ${ }^{[22]}$ ) have been used to define compliance. There are studies comparing questionnaire methods and similar results were found in the evaluation of treatment compliance ${ }^{[18-22]}$. Pill counting method and CASE compliance questionnaire were used to evaluate ART compliance of 72 patients included in our study because of its ease of use, clarity, being financially and physically accessible $e^{[16,18,19,22]}$. When the ART compliance of 72 patients included in the study was examined, 43 (59.7\%) were compliant with treatment.

The patients were most frequently between the ages of 31-40 and 51-60 (22.2\%), followed by the ages of $18-30$ and $41-50$ (19.4\%). The age range with the highest adherence to ART was 51-60 years old (32.6\%), followed by 31-40 years old (25.5\%). Compliance with treatment of patients aged 51-60 was found to be statistically significantly higher. In the study conducted by Drachler et al. on 275 HIV-positive patients receiving $A R T$, it has been found that patients aged 35 and over had higher ART compliance than patients aged $18-34^{[21]}$. 
Similar to the studies performed by Ertunc et al. in which HIV/AIDS cases have been evaluated, the disease has been found to be most prevalent among illiterate-primary school (55\%) and high school graduates (25.0\%) in our study ${ }^{[23]}$. In a multicenter study by Matharu et al. it has been found that low education level negatively affected ART compliance ${ }^{[24]}$. In our study, although 55\% of the patients were illiterate and primary school graduates, no statistically significant difference was found between educational status and treatment compliance.

In Turkey, there is no study examining the effects of smoking, alcohol and substance use and treatment compliance. Cioe et al. have reported that their study among homosexual men found no effect of smoking on ART compliance ${ }^{[25]}$. In our study, similar to the study of Cioe et al., although $52 \%$ of the patients smoked, the effect of smoking on ART compliance was not found.

Of the patients, $22.2 \%$ use alcohol and define themselves as social drinkers. In the meta-analysis of Hendershot et al., it has been stated that alcohol use affects ART compliance in a dose-dependent manner ${ }^{[26]}$. Similar results have been found in the study of Schensul et al. and treatment non-compliance was explained by avoiding the interaction of alcohol with drugs, forgetting to take the drug when drunk, and fear of stigma ${ }^{[27]}$. In our study, however, no significant difference was found between alcohol use and ART compliance. This situation was associated with the low number of our patients and the alcohol dose our patients received.

Four of our patients (5.6\%) had a history of substance use. Compliance with recreational drug use has been found to be similarly low in the study of Sonchez-Rivero et al. in Spain and in the study of Ali et al. in Pakistani intravenous drug users ${ }^{[28,29]}$. In our study, similar to the literature, it was determined that the use of substance decreased treatment compliance $(p=$ 0.023). It has been reported that substance use may affect neurocognitive functions and cause patients to forget taking medication. At the same time, it may affect adherence due to the fear of the substance interacting with $\mathrm{ART}^{[26,27]}$.
The frequency of clinical follow-up is directly proportional to treatment continuity and compliance. It should be noted that the number of missed clinical appointments in HIV patients is a risk factor for virological failure. It has been reported that motivation is higher in patients who come for control in short periods, and ART compliance is found to be higher due to the increase in incentives for compliance ${ }^{[30]}$. Similarly, in our study, it was observed that the treatment compliance of our patients who came for control in three-month periods was higher than the patients who came for longer periods.

Depressive mood may develop in patients due to factors such as stigma, isolation from the environment, and decreased social support. HIV/AIDS patients have a more depressed mood compared to the normal population. In the study of Shumba et al., it has been determined that depressive mood affects treatment compliance negatively ${ }^{[31]}$. In a study conducted on 216 patients in South America, it has been found that patients with depressive mood using the BECK Depression Scale had significantly lower treatment compliance ${ }^{[32]}$. In Turkey, there are no studies on the frequency of depressive mood in HIV/AIDS patients. In our study, $44.4 \%$ of our patients had depressive mood according to the HAM-D depression rating scale. $59.4 \%$ of the patients with depressive mood were found to be non-adherent, consistent with the literature $(p=0.007)$. It has been suggested that depressive mood reduces self-care and leads to introversion/social isolation, thus reducing treatment compliance due to deprivation of social support ${ }^{[31,32]}$.

Studies have shown that treatment compliance increases as the duration of ART use increases ${ }^{[15,18,20]}$. Unlike the literature, in our study, no significant difference was found between the duration of ART and compliance, while the compliance with treatment was found to be low in patients who were followed up with a diagnosis of HIV for more than 10 years.

The limitations of our study are that the study was conducted in a short period of time, the patients could not be re-evaluated at their next visit, and the study was performed in a single center. 


\section{CONCLUSION}

The side effects of ART and additional treatments used should be carefully monitored, especially patients should be informed about the side effects of the drugs. Patients should be followed up more frequently in order to monitor and increase compliance with treatment. Adherence to treatment was found to be lower in the younger age group, and these patients should be supported in the process of accepting the disease. Since alcohol and substance use affects treatment compliance, support should be sought from relevant institutions to limit alcohol and substance use in patients. Depressive mood is more common in HIV/AIDS patients compared to the normal population and negatively affects treatment compliance. Social support should be given to these patients by helping them in terms of lifestyle changes, and patients in need should be directed to specialists from whom they can receive psychological support.

\section{ETHICS COMMITTEE APPROVAL}

This study approval was obtained from Karadeniz Technical University Faculty of Medicine Scientific Researches Ethics Committee (Decision no: 18, Date: 08.01.2018).

\section{CONFLICT of INTEREST}

The authors declare that they have no conflict of interest.

\section{AUTHORSHIP CONTRIBUTIONS}

Concept and Design: SK, HNK, IK

Data Collection or Processing: SK, HNK

Analysis/Interpretation: HNK, MA

Literature Search: HNK, MA

Writing Manuscript: HNK, MA

Final Approval: SK, HNK, IK, MA

\section{REFERENCES}

1. UNAIDS. Preliminary UNAIDS 2021 Epidemiological estimates-global HIV statistics-Fact Sheet 2021. Accessed date: 10 June 2021. Available from: https://www.unaids.org/en/ resources/fact-sheet.

2. Republic of Turkey, Ministry of Health, General Directorate of Public Health. Ministry of Health. HIV-AIDS statistics. Accessed date: 16 June 2021. Available from: https://hsgm. saglik.gov.tr/tr/bulasici-hastaliklar/hiv-aids/hiv-aids-liste/ hiv-aids-istatislik.html.
3. Granich R, Gupta S, Williams B. 90-90-90, epidemic control and ending AIDS: Global situation and recommendations. Int J Virol AIDS 2018;(5):043.

4. UNAIDS. 90-90-90 An ambitious treatment target to end the AIDS epidemic. Accessed date: October 2014. Available from: https://www.unaids.org/sites/default/files/media_asset/90-90-90_en.pdf.

5. de Oliveira Costa J, Schaffer AL, Medland NA, Litchfield M, Narayan SW, Guy R, et al. Adherence to antiretroviral regimens in Australia: A nationwide cohort study. AIDS Patient Care STDS 2020;34(2):81-91.

6. Adrawa N, Alege JB, Izudi J. Alcohol consumption increases non-adherence to ART among people living with HIV enrolled to the community-based care model in rural northern Uganda. PLoS One 2020;15(11):e0242801.

7. Dworkin MS, Chakraborty A, Zychowski D, Donenberg G, Novak R, Garofalo R. Self-efficacy and ability to read as factors associated with antiretroviral therapy adherence in an HIV-infected population. Int J STD AIDS 2018;29(12):115464.

8. Neupane S, Dhungana GP, Ghimire HC. Adherence to antiretroviral treatment and associated factors among people living with HIV and AIDS in CHITWAN, Nepal. BMC Public Health 2019;19:720.

9. Banagi Yathiraj A, Unnikrishnan B, Ramapuram JT, Kumar $N$, Mithra P, Kulkarni $V$, et al. Factors influencing adherence to antiretroviral therapy among people living with HIV in coastal South India. J Int Assoc Provid AIDS Care 2016;15(6):529-33.

10. Abadiga M, Hasen T, Mosisa G, Abdisa E. Adherence to antiretroviral therapy and associated factors among Human immunodeficiency virus positive patients accessing treatment at Nekemte Referral Hospital, West Ethiopia, 2019. PLoS One 2020;15(5):e0232703.

11. Aye WL, Puckpinyo A, Peltzer K. Non-adherence to anti-retroviral therapy among HIV infected adults in Mon State of Myanmar. BMC Public Health 2017;17:391.

12. Moradi A, Alavi SM, Fahimfar N, Haghighizadeh MH, Mirzaei $B$. Study of determinants of adherence to antiretroviral treatment among HIV patients covered by Ahwaz Jundishapur University of Medical Sciences. Int I Med Res Health Sci 2016;5(11):477-84.

13. Amirkhanian $Y A$, Kelly JA, DiFranceisco WJ, Kuznetsova AV, Tarima SS, Yakovlev AA, et al. Predictors of HIV care engagement, antiretroviral medication adherence, and viral suppression among people living with HIV infection in St. Petersburg, Russia. AIDS Behav 2018;22(3):791-99. Formun Altı

14. Yu Y, Luo D, Chen X, Huang Z, Wang M, Xiao S. Medication adherence to antiretroviral therapy among newly treated people living with HIV. BMC Public Health 2018;18(1):825.

15. Ceylan E, Koç A, Inkaya AÇ, Ünal S. Determination of medication adherence and related factors among people living with HIV/AIDS in a Turkish university hospital. Turk J Med Sci 2019;49(1):198-205. 
16. Mannheimer SB, Mukherjee R, Hirschhorn LR, Dougherty J, Celano SA, Ciccarone $D$, et al. The CASE adherence index: A novel method for measuring adherence to antiretroviral therapy. AIDS Care 2006;18(7):853-61.

17. Hamilton M. A rating scale for depression. J Neurol Neurosurg Psychiatry 1960;23(1):56-62.

18. Hasabi IS, Shivashankarappa AB, Kachapur C, Kaulgud RS. A study of compliance to antiretroviral therapy among HIV Infected Patients at a tertiary care hospital in North Karnataka. J Clin Diagn Res 2016;10(5):27-31.

19. Kalichman S, Kalichman MO, Cherry C. Medication beliefs and structural barriers to treatment adherence among people living with HIV infection. Psychol Health 2016;31(4):383-95.

20. Salmanton-García J, Herrador Z, Ruiz-Seco P, Nzang-Esono J, Bendomo V, Bashmakovic E, et al. Self-reported adherence to antiretroviral therapy in HIV+ population from Bata, Equatorial Guinea. AIDS Care 2016;28(5):543-53.

21. Drachler Mde L, Drachler CW, Teixeira LB, Leite JC. The scale of self-efficacy expectations of adherence to antiretroviral treatment: A tool for identifying risk for non-adherence to treatment for HIV. PLoS One 2016;11(2):e0147443.

22. Wei H, Li M, Zhang X, Bu K, Feng Y, Liu X, et al. Compliance of antiviral therapy and influencing factors in people living with HIV/AIDS in Nanjing. Zhonghua Liu Xing Bing Xue Za Zhi 2015;36(7):672-6.

23. Ertunc B, Kaya S, Koksal I. Clinico-Epidemiological Analysis of HIV/AIDS Patients. Eurasian J Med 2016;48(3):157-61.

24. Bansi-Matharu L, Rodriguez Loria G, Cole SR, Mugerwa H, Vecino I, Lundgren J, et al. Risk factors for antiretroviral therapy (ART) discontinuation in a large multinational trial of early ART initiators. AIDS 2019;33(8):1385-90.

25. Cioe PA, Gamarel KE, Pantalone DW, Monti PM, Mayer KH, Kahler CW. Cigarette smoking and antiretroviral therapy (ART) adherence in a sample of heavy drinking HIV-Infected men who have sex with men (MSM). AIDS Behav 2017;21(7):1956-63.
26. Hendershot CS, Stoner SA, Pantalone DW, Simoni JM. Alcohol use and antiretroviral adherence: review and meta-analysis. J Acquir Immune Defic Syndr 2009;52(2):180-202.

27. Schensul SL, Ha T, Schensul JJ, Vaz M, Singh R, Burleson $J A$, et al. The role of alcohol on antiretroviral therapy adherence among persons living with HIV in urban India. I Stud Alcohol Drugs 2017;78(5):716-24.

28. Sánchez-Rivero I, Madoz-Gúrpide A, Parro-Torres C, Hernández-Huerta $D$, Ochoa Mangado E. Influence of substance use and cognitive impairment on adherence to antiretroviral therapy in HIV+ patients. Adicciones 2020;32(1):7-18.

29. Ali B, Nisar N, Nawab F. Adherence to antiretroviral therapy in HIV-positive, male intravenous drug users in Pakistan. East Mediterr Health J 2018;24(3):237-42.

30. Maqutu D, Zewotir T. Optimal HAART adherence over time and time interval between successive visits: their association and determinants. AIDS Care 2011;23(11):1417-24.

31. Shumba C, Atukunda R, Imakit R, Memiah P. Prevalence of depressive symptoms amongst highly active antiretroviral therapy (HAART) patients in AIDS relief Uganda. I Public Health Afr 2013;4(2):e19.

32. Moraes RP, Casseb J. Depression and adherence to antiretroviral treatment in HIV-positive men in São Paulo, the largest city in South America: Social and psychological implications. Clinics (Sao Paulo) 2017;72(12):743-9.

\section{Address for Correspondence/Yazıșma Adresi}

\section{Dr. Hanife Nur KARAKOC}

Bitlis Tatvan Devlet Hastanesi,

İnfeksiyon Hastalıkları ve

Klinik Mikrobiyoloji Kliniği,

Bitlis-Türkiye

E-posta: nurkarakoc61@gmail.com 